\title{
Huxley's Ape and Essence and Human Manipulation
}

\author{
Ruzbeh Babaee*, Wan Roselezam Wan Yahya \\ Faculty of Modern Languages and Communication, University Putra Malaysia, \\ 43400 UPM Serdang, Selangor, Malaysia \\ *E-mail address: rbabaei30@yahoo.ca
}

\begin{abstract}
In Ape and Essence (1948), Aldous Huxley indicates that people and their lives are highly controlled and regulated by disciplinary systems. Not only are people's minds controlled by the disciplines, but also physical bodies are disciplined into submission and literally taken away from their rightful owners. In fact, in Belial society of Ape and Essence, people are considered as the property of the State. Thus, their goals and ambitions revolve around satisfying the States needs. This present study shows the impacts of disciplinary systems- as a consequence of nuclear bomb- on humanity, and investigates the ways through which human beings are manipulated in Ape and Essence.
\end{abstract}

Keywords: Dystopia; Nuclear Bomb; Disciplinary Systems; Dehumanization

\section{INTRODUCTION}

In Ape and Essence, Huxley depicts Los Angeles devastated after the atomic bomb by the intelligent apes- a criticism of degradation of human race. The narration then moves to an era 100 years after the nuclear tragedy of WWIII, when atomic bomb ruined human civilization. An exploratory team from New Zealand, a region safe from nuclear damage, arrives in California to study the destruction, but they are unprepared to witness the barbarism that followed World War III. The few thousand survivors in the region have resorted to beastly methods of survival. They burn books to bake bread, and they despoil the graves of the Hollywood celebrities. Their beliefs have degenerated into worship of Belial, the personification of evil, and according to the teachings of their supreme ruler, the Arch-Vicar who insists that people have no power of themselves and they must follow what is dictated to them.

Dr. Alfred Poole, a scientist from the exploratory team, is separated from his colleagues and taken captive by the local savages. The Arch-Vicar tries to employ Dr. Poole to extend the power elite. The Arch-Vicar believes that humans have always tried to control nature during the history. By the emergence of modern machines, humans started to make advances to dominate nature. However, the price the humans paid was to become the slave of the machine that would be independent of human's skills, thoughts, and emotions. In the novel, the dystopian society worships Belial-the Satan- that severely controls reproduction in order to prevent birth defect. In Brave New World, genes are deliberately manipulated for the benefit of 
the totalitarian government; in Ape and Essence, the survivors of the nuclear bomb develop elaborate rituals for appeasing the Satan- Belial- seemingly tormenting them. In both cases, the humanity is annihilated. "Ends are ape-chosen; only the means are man's," (Ape and Essence 15) the narrator of the novel states, and argues that humans who are slaves to the biological instinct, are able to dictate only the way of their own unavoidable annihilation.

Through composing Ape and Essence, Huxley predicts that technocrat will not be the liberator but the jailor of the mankind race. Similarly, in Brave New World, Huxley makes such a prophecy and in Brave New World Revisited, he even remarks that his prediction shows signs of arriving many centuries earlier than expected. In fact, the dark utopia, which was represented from the time of H.G. Wells, becomes a serious picture of the future, and then a prediction whose evidence lies in the present.

Keith Leslie Johnson sees Ape and Essence as an "underappreciated dystopian satire" (582) and as Huxley's "secret masterpiece" (ibid.). In Ape and Essence, Huxley considers the degradation of human values in relation to technological developments, particularly the atom bomb. According to James Baker, through Ape and Essence Huxley says that "[we] have already created in reality an obscene disaster which stands as preface to the future described in this fiction" (317).

Ape and Essence is usually regarded as a criticism of the nuclear age and of the militarization of technology that can lead to dehumanization. In 1947, in a letter to Anita Loos, Huxley states his thoughts about the novel, how it is

...about, among other things, a post-atomic-war society in which the chief effect of the gamma radiations had been to produce a race of men and women who don't make love all the year round, but have a brief mating season. The effect of this on politics, religion, ethics, etc. would be something very interesting and amusing to work out. (Huxley 534)

In Ape and Essence, Huxley uses the atomic bomb as a device to encourage readers to think about the reality of bombs and science. He asks his readers to think about the idea of dehumanization that can result from uncontrolled technological advances. According to Kerwin Lee Klein, Huxley's Ape and Essence

typified an emerging genre of dystopian science fiction that imagined the declension of civil society after nuclear holocaust, but the fame of its author guaranteed the work a degree of critical attention that no pulp paperback could hope to attain. (472).

Reflecting some sentiments of The Dialectic of Enlightenment, published four years earlier in 1944, Huxley's Ape and Essence argues that western philosophy and human reason led to the creation of atomic bomb. Horkheimer and Adorno explain

Enlightenment, understood in its widest sense as the advance of thought, has always aimed at liberating human beings from fear and installing them as masters. Yet the whole enlightened earth is radiant with triumphant calamity. (1)

It seems that Horkheimer and Adorno talk about Hiroshima, and express the essence of scientific desire making such horrible event possible. Hiroshima was an inescapable modern 
disaster. Ape and Essence can be seen as a reflection of Hiroshima atomic event. Through Ape and Essence, Huxley asks us to think about humanity in our own world and the price that we paid for nuclear bombs.

In Ape and Essence, Huxley sees the mastery of human over nature through science and technology and finds the nuclear war as the consequence of this mastery. Similarly, in Discipline and Punish, Foucault challenges the Enlightenment science, and argues that every victory of Enlightenment's promise of freedom leads to insidious kinds of domination and control that is manifested through disciplinary power in the twentieth century.

The essential condition of this power is to be ubiquitous, to permeate every layer of society and regulate people, their actions and thoughts. Thus, in order to remain omnipresent and have total control over human lives, discipline is employed on all levels of society as the most crucial tool to establish supreme control. The system of severe, never-failing discipline is applied in dystopian societies and used to manipulate people's bodies and minds to ensure the maximum power of the state. This idea of discipline as an essential component of political power is the focal point of Michel Foucault's book Discipline and Punish, where he examines various ways discipline functions in society. Foucault believes that discipline is a powerful agency used to govern people's lives "to produce subjected and practiced bodies, docile bodies" that can be "manipulated, shaped," and "trained" for the benefit of the state (136-138). This study relies on the Foucault's interpretation of discipline, because it proves to be important in analyzing ways government attempts to spread and maximize its power over people's bodies and minds in Huxley's Ape and Essence. The phenomenon of "docile bodies" and "disciplined minds" as the products of discipline and direct "objects and targets of power" are especially interesting to us, as, in this paper, we aim to examine how human bodies and minds are controlled and exploited by the totalitarian postwar state.

Discipline is used to control people's everyday lives in the form of a strictly regimented routine where people's actions are prescribed by the government-instituted schedule. Thus, dystopian citizens do not have a choice in what they can or cannot do, have lost the control over their own bodies and minds, and have become "imprisoned" in the state's disciplinary system. Although Foucault published Discipline and Punish more than 30 years after Huxley's selected fiction, his ideas of disciplinary society and biopower are traceable in Ape and Essence in which Huxley illustrates human manipulation through disciplinary systems. For Huxley, disciplinary systems manipulate both human mind and body. In this paper, I mainly analyze the portrayal of docile bodies and disciplined minds in Huxley dystopian narrative Ape and essence through the lens of Foucauldian theory of biopower and disciplinary systems.

Foucault argues that the body is formed by discourse. The body's behaviors mirror the dominant discourse; this discourse defines our lifestyle, thought and language. By perceiving people as "subjects," the state discovers a way to use the human body to its full potential to ensure the maximum productivity of the general populace for the state's overall well-being. This is achieved through the manipulation of the human mind, materialized in ideological indoctrination, to ensure people's total acceptance of the ruling ideology and total compliance to the state's mandates so that they can become the country's main productive force. The discipline in dystopia "fixes . . . and arrests or regulates movements," does not just control the body, but anipulate the human mind as well (Discipline and Punish 219). In this case, the control of the body and mind has to be applied simultaneously, because people's physical performance is directly interconnected with their psychological conviction in the correctness and usefulness of their actions. In Discipline \& Punish, Foucault describes that the 'disciplinary society' tries "to induce in the inmate a state of conscious and permanent visibility that assures the automatic functioning of power" (201). Foucault argues that this new method of governing 
is systematized in such a way that it monitors every aspect of a citizen's life. The goal of such a society is to make citizens more profitable and productive, and less individual. Discipline is imposed upon people, both mentally and physically, whereby the "[d]ocile body is a disciplined and practiced human form that serves as the physical expression of subjection and conformity" (Discipline \& Punish 138). Foucault identifies the emergence of such disciplinary power as a gradual process in which the subjected body becomes quite interdependent:

The human body was entering a machinery of power that explores it, breaks it down and arranges it. A political anatomy, which was also a mechanism of power, was being born; it defined how one may have hold over others' bodies, not only so that they may do as one whishes, but so that they may operate as one whishes, with the techniques, the speed and efficiency that one determines. (Discipline \& Punish 137-38)

By disciplines Foucault means the educational, technological, and medical systems that control the body and mind. Thus, power is not represented by the inclusion or exclusion of the body from particular physical space, but instead through the control used over mind and body. In order to turn human beings into a docile bodies and disciplined minds, first, the human mind must be manipulated to believe in the correctness of the functioning of the body. The notion of discipline as a significant part of 'biopower' (literally it means control over human bodies and minds) is Michel Foucault's main concern in Discipline and Punish, in which he explores different approaches to discipline functions in society. He observes that discipline is a force employed to control humans "to produce subjected and practiced bodies, docile bodies" that can be "manipulated, shaped" and "trained" for the benefit of the state (136-138).

In the dystopian society of Ape and Essence, people have no say in what they want to do and no control over their own bodies and minds; they are just become imprisoned within a disciplinary system developed by the totalitarian government. In such a case, the mind and body must be controlled simultaneously, since humans' physical performance directly depends on their psychological belief in the righteousness of their actions.

I observe in Ape and Essence, atomic bomb paves the way for the emergence of disciplinary systems that turn people into more than docile bodies and disciplined minds; people become dehumanized and animal-like. Herbert Kelman argues when someoneindividually "independent and distinguishable from others, capable of making choices" and communally as a "part of an interconnected network of individuals"- loses his/her identity, he/she becomes dehumanized (301). In Ape and Essence, it is the government that constructs the identity of the inhabitants who are deprived of individuality and have no authority to decide for their own life.

In Ape and Essence the atomic bomb gave birth to disciplines such as ignorance, sexual habits, rituals, and hedonism. Disciplinary systems are employed to generate acceptable individual subjects, to make 'their' values and control their manners. Foucault's theory of discipline definitely seems relevant to the totalitarian government of Ape and Essence constructing the identity of its inhabitants and manipulating them through disciplinary ways.

Thus, for the present study, it is of great significance to probe human manipulation after atomic event. Through a close investigation of Huxley's Ape and Essence, we attempt to answer the question that how atomic event led to human manipulation? Foucault's theory of discipline definitely seems relevant to the totalitarian government of Ape and Essence that constructs the identity of its inhabitants and manipulates them through disciplinary ways. In 
the postwar society of Ape and Essence, the leader of the society uses knowledge and produces truth to manipulate the mind as well as the body of the citizens.

\section{NUCLEAR BOMB AND DEHUMANIZATION}

In Ape and Essence, Huxley maintains the idea that science innately is careless about destructive consequences. Material advances are costly for humans and they are not more than retrogression in human civilization. Even if nuclear weapons had not been invented, idiotic people would eventually discover a way to ruin the universe in one way or another. As the Arch-Vicar states:

He foresaw that men would be made so overweening bumptious by the miracles of their technology that they would lose all sense of reality. And that's precisely what happened. These wretched slaves to wheels and ledger began to congratulate themselves on being the Conquerors of Nature and were about to suffer the consequences. (Ape and Essence 43)

The Arch-Vicar believes that modern science provides human "with the instruments for progressing and indiscriminate destructions" (43). A false belief in science has led the humankind, ever more gullible and docile, to have belief in the vain hope of a future utopia. Human beings have become enslaved to technology that has created an illusion of utopia for them.

The dystopian narrative in Ape and Essence considers the danger of unlimited technology. Huxley shows how the nuclear destruction took place. Technology has been blindly developed for years, and the existent civilization illustrated in the novel represents no redeeming solution. The scenario begins with the narrator's voice reflecting on the material utility that shows Los Angeles in the 1940s:

And in the midst of them the City of the Angels.

Half a million houses,

Five thousand miles of streets,

Fifteen hundred thousand motor vehicles,

And more rubber goods than Akron,

More celluloid than the Soviets,

More Nylons than New Rochelle,

More brassieres than Buffalo,

More deodorants than Denver,

More Oranges than anywhere,

With bigger and better girls-

The great Metropolis of the West. (21)

But, now the metropolis is observed as a ghost city in which all machineries stand idle and the residents are regarded as a mass of savages who make their life by plundering graves. In this ghost city, the radioactivity after the nuclear attack leads to a generation of deformed human beings who have moved back to the primitive state of existence before the year 900 B.C. (Ape and Essence 62). Nuclear event led to deformity that can be seen as a kind of dehumanization. According to Bogdan and Taylor, in "Relationships with severely disabled people," in order to erase the attitude of dehumanization towards the disabled, they should be 
given "social place" in the society. But, in Ape and Essence, "the priests don't let the deformed babies go on living" (27) and kill them in "the Purification ceremony". In fact, the government sees no right for the deformed babies and kills them against their mothers' will. Huxley shows the Satan achieves his goal of dehumanization by

using human beings and their sciences as His instruments. He created an entirely new race of men, with deformity in their blood, with squalor all around them and ahead, in the future, no prospects but of more squalor, worse deformity and, finally, complete extinction (Ape and Essence 45).

Huxley considers this birth defect inescapably emerges from the constant exposure to radioactivity and becomes more common as a consequence of nuclear weapons. The horror of the nuclear weapon increased Huxley's fear of uncontrolled technology that the government uses to manipulate people. Huxley considers the cause of technological pride, and declares that materialistic philosophy associates with dehumanization and a growing indifference to human norms in modern era. According to him, in "Science, Liberty and Peace", this materialistic view reduces the human beings to mere docile bodies:

Human beings, it is more or less tacitly assumed, are nothing but bodies, animals, even machines; the only really real elements of reality are matter and energy in their measurable aspects; values are nothing but illusions that have somehow got themselves mixed up with our experience of the world; mental happenings are nothing but epiphenomena, produced by and entirely dependent on physiology; spirituality is nothing but wish fulfillment and misdirected sex; and so on. (37)

In war time, the materialistic view resulted in general massacre and annihilation, and in days of peace it encouraged cruel attitudes and brutal manner. Humans must change their viewpoints to be able to observe that the ultimate goal of life is not located in the utopian future but human gratification is in the "timeless eternity of the Inner Light." A reductionist perspective raised via modern technology is the main resource of evil and destructive modern norms (Ibid. 38-39).

\section{DISCIPLINES OF CONTROL}

In Ape and Essence, Huxley depicts how the totalitarian state exploits, regulates and controls the human body and mind via disciplinary coercions to ensure its full productivitypotential and utter submission. In Belial society, people are treated as "as object and target of power" (Discipline and Punish 136), intending to eventually produce "a body-weapon, bodytool, body-machine complex" (Discipline and Punish 153). This strategy fulfills two goals at once: the more docile and obedient the body becomes, the more useful and productive a tool it evolves into. Elaborating on this disciplinary tactic, Foucault argues that "the disciplinary coercion establishes in the body the constricting link between an increased aptitude and an increased domination" (Discipline and Punish 138). Through the dystopian society of Ape and Essence, Huxley portrays various disciplinary coercions that achieve both a docile and productive body. The routine that the government instills in people warrants the creation of docile bodies and ensures their docility in every aspect of everyday life. As Foucault contends, 
the prescribed timetable develops "a collective and obligatory rhythm," "assures the elaboration of the act itself," "controls its development and its stages from the inside" (Discipline and Punish 152). Also, prearranged social functions, with which each dystopian citizen is labeled in dystopian society, become another embodiment of the discipline. Thus, the government uses disciplinary ways such as ignorance, rituals, sexual habits, moral exclusion, and hedonism that all emerged after the atomic bomb to manipulate the inhabitants and to ensure that each individual is used to its full potential for the benefit of the state.

\section{1. Ignorance}

After the nuclear event, the survivors in the area are resorted to beasty approaches of survival. They burn books for baking, and pillage the graves. The government keeps the inhabitants in ignorance to manipulate them mentally. The inhabitants' ignorance gives the government power. Indeed, the government uses this ignorance as a discipline to control the inhabitants.

In the society of Belial no one, except the priests, knows how to read. Children are not taught to read and write in school. Classes are conducted on a vocal level only. Satanic Science Practitioners employ techniques that remind one of the conditioning exercises in Brave New World for introducing necessary lies, teach students that "the chief end of Man is to propitiate Belial, deprecate His enmity and avoid destruction for as long as possible" (Ape and Essence 31). Such knowledge appears to be all that the student learns in school. The ruler keeps the citizen in ignorance to manipulate them easily.

\section{2. Purification Ceremony}

Ritual is another kind of discipline that is used by the government. In the dystopian society of Ape and Essence, people with more than "three pairs of nipples" or "seven toes and fingers" get liquidated at the "Purification ceremony" (29). During the Purification Ceremony children born with more than "three pairs of nipples and seven toes and fingers" are seen "monsters" and will be legally "liquidated" (29). The children along with their mothers go to the "High Altar," and the Patriarch of Pasadena takes the children by their neck and plunges them into a dagger held in his other hand. This is a sacrificial ceremony for Belial. The mother of the executed child is taken away by two Postulants who strike "at her savagely with their consecrated bulls' puzzles" (40). The mother is returned to the community with shaved heads as the "vessel of Unholiness" (38).

This discipline sustains the people's cruelty. Instead of being compassionate or show empathy towards the mothers and their children, they ask for more blood. The "Purification ceremony" is the outset of "five week" ceremony during which females go through a kind of "actual mating". Huxley depicts this custom as scared. Dr. Poole, a scientist from an exploratory team from New Zealand, watches infants murdered and sees mature adults display their sexual appetites in a mode that should be explained as indecent and animal-like at best. Then, his reflection is: "It's monstrous! , . . It's utterly revolting" (46). The Satanic society typically descends humanity to the degree of the animal. Critics argue the likening of individuals to animals attributes to degradation and humiliation of humanity. Paul Rozin states: "Insofar as humans behave like animals, the distinction between humans and animals is blurred, and we see ourselves as lowered, debased" (642). The inhabitants of the Satanic society have an animal-like life, relying on instinct rather than rationality for their survival. The inhabitants have no voice to question the brutal ritual. 


\section{3. Sexual Instruments}

In Ape and Essence, women live in a misogynistic society in which they are doomed to accept their predestined fate. In the Satanic society of Ape and Essence, women are seen as "the vessel of the Unholy Spirit, the source of all deformity, the enemy of the race" (25). Sherry Ortner observes that in a dehumanized society, females represent "a lower order of being, as being less transcendental of nature than men" (73), and being female is equal to animality, childlikeness and "the enemy of race."

In Ape and Essence, except for the night of the ritual and a two-week period thereafter, sex is illegal. To reinforce the law, women must wear small patches embossed with the word "No" over the breasts and other areas of possible temptation. Anyone who has sexual adventures during the remainder of the year is labeled a "Hot" and is severely punished.

During Unconditional Surrender, Belial permits his followers to reproduce for two weeks. Belial's permitting such mating, through his ministers, is hypocritical because predetermined mating denies human nature. Thus, the god's ministers enforce provisos in which they do not believe and it is not important for them how much the facts of the matter may be perverted. Sexual habits become just an act. Reproduction has been reduced to its most basic level, devoid of sensitivity and morality. The followers of Belial are allowing themselves to be conditioned into a lower life from wherein is only one short mating season, rather than the unlimited ones people have evolved for themselves.

\section{4. Moral Exclusion}

Moral exclusion is another discipline to control humanity. Susan Opotow argues moral exclusion is when people are regarded as "outside the boundary in which moral values, rules, and considerations of fairness apply" (1). Accordingly, in the novel, the people imagine themselves out of human boundary and quite obedient to the Satan's commands.

Morality becomes a mockery for this Belial society. Those people who possess moral consciousness such as Dr. Poole and Loola, a local girl, escape from this immoral world, and set forth to begin again. Dr. Poole is an outsider and aware of the discipline that is imposed on the inhabitants. However, he sometimes worships and participates in some of the rituals in order to avoid of any suspicion.

Dr. Poole and Loola's love is a moral love, and he believes that nothing will happen to them if they resist Belial and his rituals. Poole and Loola decide to trust and love each other, despite all the limitations. Both of them attempt to possess free will instead of blind obedience. Loola is innocent since she lives in a society in which people are suppressed both mentally and physically. The misogynistic society accuses Loola's gender of all Unholiness, and trains women to be ignorant and accept their condition unquestionably. She experiences the savagery of the society through rituals, and is unable to change the situation. She lives in her ignorance. Before meeting Dr. Poole, Loola had an animal-like life, relying on instinct instead of rationality. But Dr. Poole gives her knowledge and makes her aware of the condition. The most significant difference between Loola and other inhabitants is that she gains moral consciousness that makes her able to see the reality of her society. Finally, Dr. Poole and Loola decide to leave the satanic society and experience a life different from the one in Belial savage society:

Love, Joy and Peace - these are the fruits of the spirit that is your essence and the essence of the world. But the fruits of the ape-mind, the fruits of the 
monkey presumption and revolt are hate and unceasing restlessness and a chronic misery tempered only by frenzies more horrible than itself (64).

Dr. Poole and Loola find love, joy, and peace as the tools that can rescue them from the dystopian satanic world in which people are kept in ignorance and barbarity through disciplinary systems.

\section{CONCLUSIONS}

To sum up, Huxley's Ape and Essence is a dystopian one, full of imperfection caused by both nuclear bomb and disciplinary ways that dehumanized human beings. Huxley represents a pessimistic expression in Ape and Essence that illustrates a world of destructive power and erosion of humanity. Ape and Essence represents a world on the edge of destruction, with a group of survivors being deprived of free will and the individuals who have to obey and to live in a devastative society after the atomic bomb that is the consequence of the Enlightenment reason and science. Huxley's novel also depicts the decadence of individuals through disciplines such as sexual immorality, moral exclusion, ignorance, and rituals. Huxley shows that atomic event gave birth to disciplinary systems led to dehumanization in Ape and Essence.

In Belial society, individuality and any personal expression or creativity are prohibited. Any rebellion against the regime is eliminated through indoctrination, so that nothing can challenge the current apparatus of political power. Nevertheless, some people like Dr. Poole and Loola are able to see the horrible injustices of the state's system and dare to speak out against it. By the help of Dr. Poole, Loola is able to discover her inner self and reclaim her individuality, to break through her indoctrinated and "social" self, and regain her body and mind. Consequently, this act of self-discovery grants people like Loola an invaluable opportunity to look at their lives from a different perspective, detect cracks in the state's system, see and understand their repressed lifestyles, and find the will to rebel against it.

\section{References}

[1] Adorno T. W., Max H., Dialectic of enlightenment: Philosophical fragments. Stanford University Press, 2002.

[2] Baker J. R., Twentieth Century Literature 46(3) (2000) 311-327.

[3] Bogdan R., Steven J. T., Social problems (1989) 135-148.

[4] Foucault M., Discipline and Punish. New York: Vintage. 1979.

[5] Huxley A., Ape and Essence. Vintage, 2005.

Science, Liberty and Peace. New York: Harper and Brothers, 1946.

[6] Huxley J., ed., Aldous Huxley: 1894-1963: A Memorial Volume. New York: Harper \& Row. Includes contributions from Isaiah Berlin, David Cecil, T.S. Eliot, Gerald Heard, Robert M., Hutchins, Gervas Huxley, Juliette Huxley, Julian Huxley, Christopher Isherwood, Anita Loos, Raymond Mortimer, Humphry Osmond, Steven Runciman, Osbert Sitwell, Stephen Spender, and Leonard Woolf, 1965. 
[7] Johnson K. L., Twentieth Century Literature, Darwin and Literary Studies 55(4) (2009) $572-596$.

[8] Kelman H. C., "Violence without restraint: Reflections on the dehumanization of victims and victimizers." In Kren, George M., and Leon H. Rappoport. Varieties of psychohistory. New York: Springer (1976), 282-314.

[9] Klein K. L., Pacific Historical Review 70(3) (2001) 465-476.

[10] Opotow S., Journal of social issues 46 (1990) 1-20.

[11] Ortner S. B., "Is female to male as nature is to culture? In M. Z. Rosaldo \& L. Lamphere"(Eds.), Woman, culture, and society Stanford, CA: Stanford University Press, 1974.

[12] Rozin P., Jonathan H., Clark M. "Disgust". In M. Lewis \& J. M. Haviland-Jones (Eds.), Handbook of Emotions New York, Guilford, 2000. 